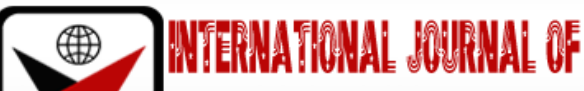

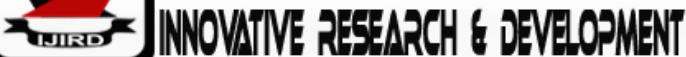

ISSN 2278-0211 (Online)

\section{Service Quality and Customer Loyalty in the State Banks in Sri Lanka}

\author{
Dr. Sriyani Ranasinghe \\ Senior Lecturer, Department of Entrepreneurship, Faculty of Management Studies and \\ Commerce, University of Sri Jayewardenepura, Sri Lanka
}

\begin{abstract}
:
Purpose- The purpose of this empirical research is to find the relationship between Service Quality and Customer Loyalty with special reference to State Banks in the Kaluthara District of Sri Lanka.

Design/ Methodology/ Approach-A self-developed theoretical framework is proposed by the author based on the relationship between five main independent variables and customer Loyalty in the state banks using: Service Reliability, Assurance, Tangibility, Empathy and Responsiveness. Self-developed structured questionnaires were distributed among 256 of customers in the Kaluthara District and collected data were analyzed using Pearson correlation analysis.

Findings-Results indicate that there is a positive significant impact of selected independent variables except the Service Tangibility dimension and the Customer Loyalty. The finding of the results indicated that Service Reliability dimension is the most effective relationship to customer loyalty in the State Banks in the Kaluthara District, Sri Lanka. Research Implications- The study is limited to Service Quality. The scope of the study is narrowed to the State Banks in the Kaluthara District, Sri Lanka, who were selected through convening sampling method in this pandemic situation in Sri Lanka.

Practical Implications- The findings suggest recommendations to enhance the customer service qualities such as promote state banks through new technology in Sri Lanka, improve the innovation to satisfy the customer, improve effective customer data base, advisory banking online systems.

Originality/Value- The study suggests that that the theories regarding service qualities adopted from western developed countries should carefully test and examined before them relating to developing Asian country like Sri Lanka.
\end{abstract}

Keywords: Customer loyalty, service quality, reliable, empathy, accuracy, responsiveness

\section{Introduction}

Banks tend to accept money from customers who have surplus funds and provide money as loans and advances to the customers with deficiency of finances (Alhkami\&Alarussi, 2016,). The difference between the two interest rates is effectively the profit margin for banks. A vital role is played in the economy, by banks through providing a service for individuals who wish to save and equally important task of offering finances for businesses in order to invest and expand (Bakar\& Econ, 2018). Any country is benefitted by these loans while business investments are essential for economic growth (Bashir Ahmad Fida, 2018).

Recent literature suggests that in order to have sustainable economic growth and to survive the tough competition as a result of innovative and creative products and services of the organizations, many vital factors are essential (Morawakage \& Kulathunga, 2013). Service quality is measured through the customers' viewpoint until (Sein and Chey, 2013) in this study. One of the very conspicuous aspects in banking is the customer loyalty, which is vital due to tough rivalry and advanced customer expectations in the competitive situation of the market (Khan, \&Rizwan, 2014). Concentrating on provision of an exceptional service and fulfilling the needs of customer (Al-Msallam, 2015) is one of the methods to enrich customer loyalty in the banking. In order to implement suitable marketing strategies aimed at relationship building and customer retention, the banks need to understand their customers' behavior Al-Balushi1 \& Singh, 2020). Retaining existing customers in a bank is much valuable rather than getting new customers due to the cost effectiveness. A key factor for the profitability of a business is customer loyalty (Wirtz et al., 2013). In the absence of loyal customers banks cannot operate smoothly for a long duration (Chevan\& Ahmad, 2013). Customer loyalty can be regarded as a crucial factor for both the institute and the customers. Al-Rousan et al., (2010) described the customer loyalty as 'the marketplace currency of the twenty-first century'. Pfeifer (2005) explained that in the banks, the cost of serving a loyal customer is five or six times lower than a new customer. Indisputably, the quality of customer satisfaction in banking service has a sophisticated link with the manner of the evaluation of service quality (Rahim, 2016). Hence, an excellent level of service quality needs to be provided by the banking personnel in order to establish and sustain customer satisfaction. Careful inspection of the services marketing literature reveals that majority of the prevailing research into 
associations among service quality, and customer loyalty is based on samples obtained from the developed western countries. In addition, many studies have used, adapted, or replicated model of the SERVQUAL, despite problems associated with its dimensionality and the strength in various contexts, to measure service quality.

The focus of this study is to analyze the association between Service Quality and Customer Loyalty of State Banks in Kaluthara District in Sri Lanka. In relation to the subject, few specific details are mentioned in relevant to the four State Banks. They carry on providing financial assistance and advisory services to local entrepreneurs of all caliber especially for those who have the perseverance to attempt their own success and struggling for empowerment with financial challenges. State Banks serve as a financial pillar of the communities by facilitating personal and socio-economic development in offering assistance to personnel without bias, purely on trust and maturity that emanates with over 35 years of service to the nation (Annual Report, 2019).

\subsection{State Banks Financial Process}

The financial highlights for banks are slightly changed from most organization that stockholders analyze. There are many unique attributes of bank financial highlights that comprise how the balance sheets and income statements are laid out. However, once investors have an indestructible sympathetic of how banks earn revenue and how to analyze what is driving that revenue, bank financial highlights are relatively easy to understanding. Growth, loans and receivables and customer deposits are few of them of these banks.

\subsection{Growth Process}

State Banks are premier state-owned development bank in Sri Lanka, and it is a 100\% state owned bank that was set up with the objective of improving the living standards of the rural community of Sri Lanka. One of the financial highlights is a growth. Growth will come from a grouping of projects in three areas: emerging the essential business of the bank, capitalizing in adjacent business areas, and touching into completely new product-market parts. Figure 1 expresses the growth of State Bank1 from 2010 to 2019 as below.

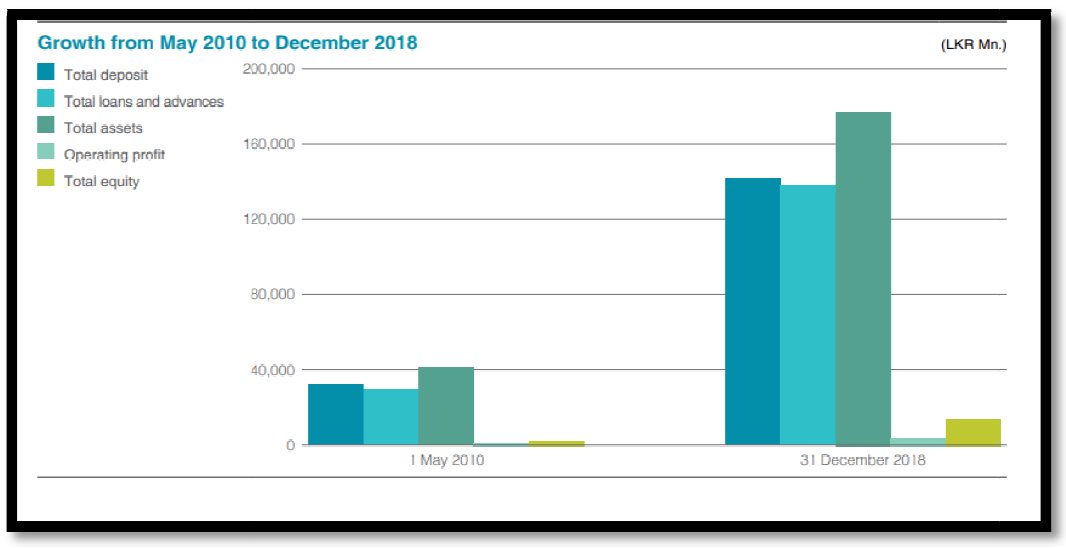

Figure 0: Growth of State Bank 1 from 2010 to 2019

Source: (Annual Report, 2019)

\subsection{Loans and Receivables}

Loans and receivables are the non-derivative monetary assets with secure or determinable expenditures that are not quoted in an active market. They characteristically arise when an object provides money, goods or services directly to a debtor with no meaning of trading the receivable. Figure 2 presented the loans and receivable.

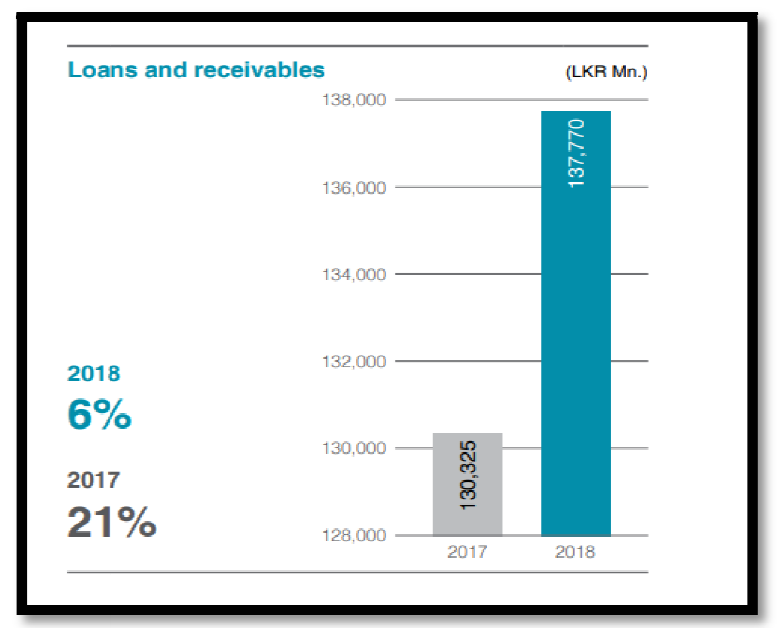

Figure 2: Financial Highlights - Loans and Receivables Source: (Annual Report, 2019) 


\subsubsection{Customer Deposits}

State Bank 1 has a network of 278 branches in Sri Lanka while the existing customer base is more than six (6) million customers, and the increase was 4 million customers when compared with year 2011 (Annual Report, 2019). Following figure, 3 presents the increase of customer-based deposits.

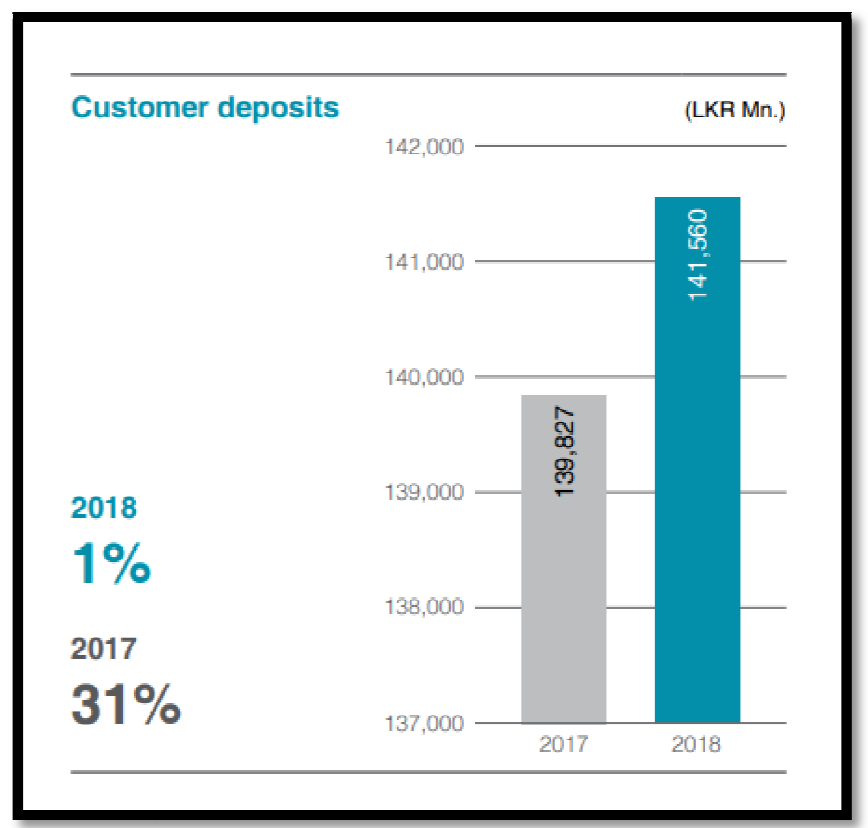

Figure 3: Customer Deposits Source: (Annual Report, 2019)

\subsubsection{Stable Credit Rating}

Credit constancy is the aptitude or volume to largely maintain credit quality under circumstances of reasonable stress. The primary emphasis of credit constancy is ordinary business risk somewhat than special types of risk, such as vicissitudes in laws, fraud, or corporate attainments. Figure 4 presented the BBB+ stable credit rating.

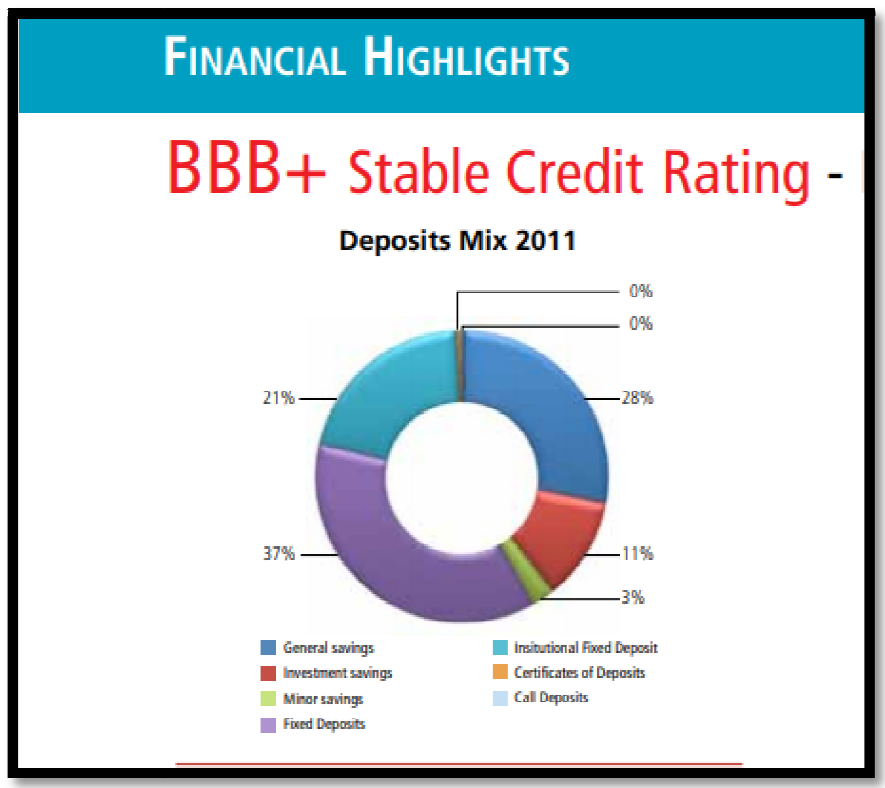

Figure 4: BBB+ Stable Credit Rating - (Annual Report, 2011)

\subsection{State Banks in the Kalutara District in Sri Lanka}

Originally set up to supply the governments' financial needs, State banks evolved into consumer organizations to serve millions of customers with a wide range of financial products. With branches in most towns and villages, they also undertake commercial as well as personal banking. The research study is conducted in Kaluthara district in Sri Lanka and Figure 5 presents the map for the State Banks. 


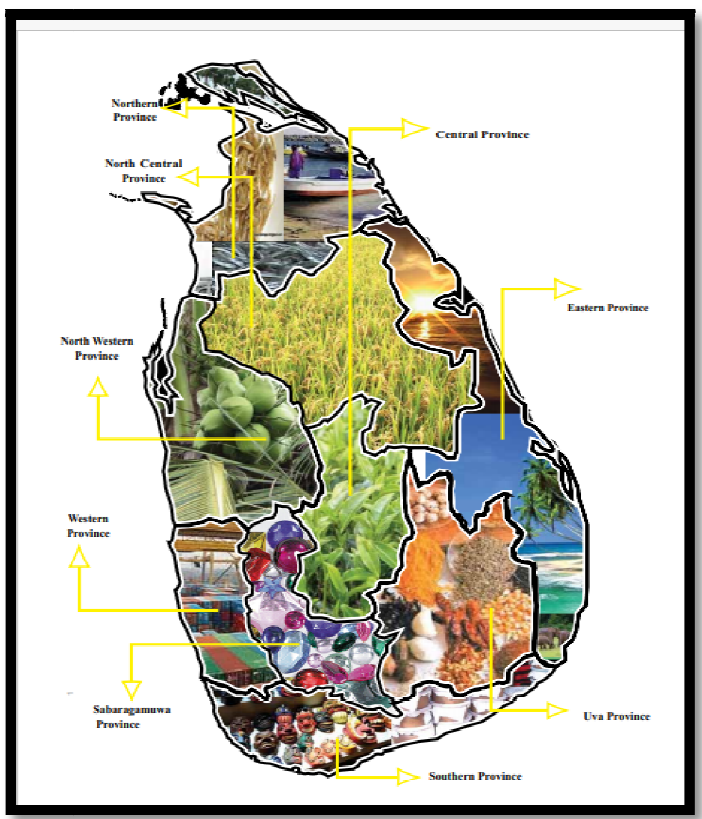

Figure 5: The Map for the State Banks in the Kaluthara District

Kalutara District data was reported at 11.000 Units in 2017. This records a decrease from the previous number of 12.000 Unit for 2016. Kalutara District data is updated yearly, averaging 11.000 Unit from Dec 1998 to 2017 , with 20 observations. The data reached an all-time high of 12.000 Unit in 2016 and a record low of 6.000 Unit in 2003 . Kalutara District data remains active status is reported and the data is categorized under Global Database's Sri Lanka (Central Bank of Sri Lanka, 2019). According to the annual report of central Bank (2019) Kaluthara District has 12 state banks at present namely Merchant Bank, Seylan Bank, National Savings Bank, DFCC Bank, Regional Development Bank, Sanasa Bank, People's Bank, National Development Bank, National Trust Bank, HDFC Bank, Sampath Bank and Bank of Ceylon. The study selected only four banks with the limited capacity of the resources.

Literature exposes that service quality and customer loyalty are important features in relation to causality and relationships in the midst of unclear, inconsistent and controversial subject matter (Auh\& Johnson, 2005). Service quality and customer loyalty have been identified by them as corresponding or conflicting constructs. Some other researchers additionally recognized the causal mutuality of service quality and customer satisfaction, which generated more perplexity (Wang and Chich-Jen, 2006). Likewise, the assertion that customer satisfaction directs to loyalty seems even less conclusive (Pritchard \&Silvestro, 2005). However, it is noteworthy that several studies have been conducted to examine these relationships in the Sri Lankan banking industry. Similarly, in order to analyze customer perceptions of service quality, a large number of current studies have primarily been encouraged by the SERVQUAL framework although it has been stated to be insufficient in the banking context, creating increasing debate to enrich its toughness (Pakdil, Aydin, 2007).

Correspondingly, the large number of previous research on service quality in Sri Lanka indicates that a relatively greater attention has been paid to the telecommunications industry as literature reveals (Olatokun and Nwonne, 2012; Gambo, 2013; Moguluwa and Ode, 2013). Strangely, the few studies relating to the Sri Lankan banking industry (Wijeratne, 2015; Ranathunga and Weerasekara, 2017) show that the researchers paid inadequate attention to the SERVQUAL model.

It is prominent that most of these studies were done for firms but not industry level investigations. However, in spite of the emphasis and the anticipated higher progression of bank transactions in developing countries, it is evident that the banking sector in Sri Lanka has not been given desired research attention it deserves. This study seeks to address the gap in the service quality literature by investigating the impact of perceived quality services and the satisfaction of the customers on the customer loyalty in the State Banks in the Kaluthara district, Sri Lanka.

Service quality is the vital theme of this research study and it is essential to understand what service quality is; its benefits; and why it is being used to measure service quality. Service quality is abundantly represented in literature mainly in relation to various private and public sectors around the world. Majority of the available literature are on either banking, airlines, hotels, and restaurant sectors. Service quality and customer loyalty are essential factors in the current global economy for survival, profitability, and productivity of the business. Service quality contribution is the most important factor to investigate the customer loyalty in any business, whether manufacturing, service, or any other kind of business.

The scale introduced by Parasuraman et al. (1998), to measure the service quality is one of the vital contributions to the field of service quality and is very popular. Several researchers have evaluated the impact of the perceived service quality and customer loyalty in the international banking sector but only few studies have yet been done with regard to relationships in the Sri Lankan context (Wijeratne, 2015; Ranathunga and Weerasekara, 2017).

Further, measurements of service quality in deactualizations in different countries. Hence, it is not viable to generalize research findings of other countries to Sri Lanka which endorses the requirement to carry out further research on the aspect of service quality to enhance the customer satisfaction. Few researchers claim that perceived values hold a stronger contribution for the influence of service quality and customer satisfaction. In Nigeria, considerable number of 
earlier research done on service quality concentrated on banks and the telecommunications industry (Olatokun, Nwonne, 2012; Gambo, 2013; Moguluwa, Ode, 2013).

The SERVQUAL model has been found as reliable factors and an appropriate tool to measure, evaluate, support, and improve the quality of services in banking industry. It shows that customer complaints against the service matters are on the increase and customers tend to move away from the bank and turnover has been increasing continuously (Ranathunga, 2016). Faster growth rate of bank transactions is expected in developing countries. The banking sector in Sri Lanka appears to be given somewhat less attention in research than it requires. It has been identified that the branches of State Banks in the Kaluthara district have been facing the difficulties since few years' time according to the progress report (2018) of them such as high customer turnover, increasing customer complaints, decreasing repurchasing power, and decreasing market share of the banks. Hence, this research study attempts to address the research problem of 'Whether there is a relationship between service quality and customer loyalty of State Banks in the Kaluthara District, Sri Lanka?' The objective of this study seeks partially address the gap in the service quality literature attention to study the association between Service Quality and Customer Loyalty of State Bank in the Kaluthara district, Sri Lanka.

In order to manage research effectively, it is important to identify the scope of the research study. Here, this research is limited to Kaluthara district in Sri Lanka due to the difficulty of gathering data from the total number of customers of the banking the country. The study would aim to generalize the findings of the research to the entire state banks context. Further, it is expected to collect data from 320 customers from Kaluthara district Sri Lanka. Due to the reasons of pandemic situation at the present context in Sri Lanka. It was not in a position to complete the study as planned and few modifications have done with the limited capacity.

\section{Literature Review}

There is comprehensive research work is done by many researchers and authors in the field of the quality of service and the customer loyalty in the area of banking during past on this topic to finding the determinants, variables and also factors affecting in the outlook of quality of the provided service and loyalty. It is very much important to have a clear understanding about the opinions, findings and recommendations of the other scholars relating to the similar research area and based on that researcher has done critical investigation in the literature to find out relationship between service quality and customer loyalty.

Services are increasingly becoming a large portion of any organization and being considered as indispensable tool for revenue stream (Dhandabani, 2010). Quality of the service provided has elaborated with parallel to the customer expectations and actual perception of the service (Parasuraman, Zeithaml and Berry, 1988). According to the literature, the quality of the service provided can be expressed as the gap between consumer's perception and expectation which is the output resulted from comparison between the two states. When it comes to the Banking sector the quality of the service provided to the customer plays a significant part in overall satisfaction of the customer.

There are number of factors influence to customer loyalty. Quality of the service provided is among the important factors among them. Simply Quality of the service provided is the consumer's appraisal of a service's overall quality. It can be differing person to person, industry to industry and there are so many models to assess quality of the service provided. However, the measurement of quality of the service provided has become the most difficult task for organization.

Moreover, literature has highlighted the few theoretical models and approaches to the area of the study. These models show the relationship between the Service Quality and Customer Loyalty in a theoretical based. The SERVQUAL Model is the based model which was developed by Parasuraman (1992) for the most of the research measuring the service quality variable. New trend of research, which connects it to electronic customer loyalty and found that Service Quality has a significant and positive association (Raza et al., 2020). The service provide chain is expressed the views that operating strategy and service quality system of the productivity of the institutes has an association (Sureshchandar et al., 2001). The one of the modes highlighted that mediator effect of the relationship between the independent and the dependent variable relationship between the Survive Quality and Customer Loyalty (Gilbert and Wong, 2003). One of the famous models is developed by Olah (2018) consists with its eight dimensions. Figure 6 presents the association between service quality and customer loyalty as below.

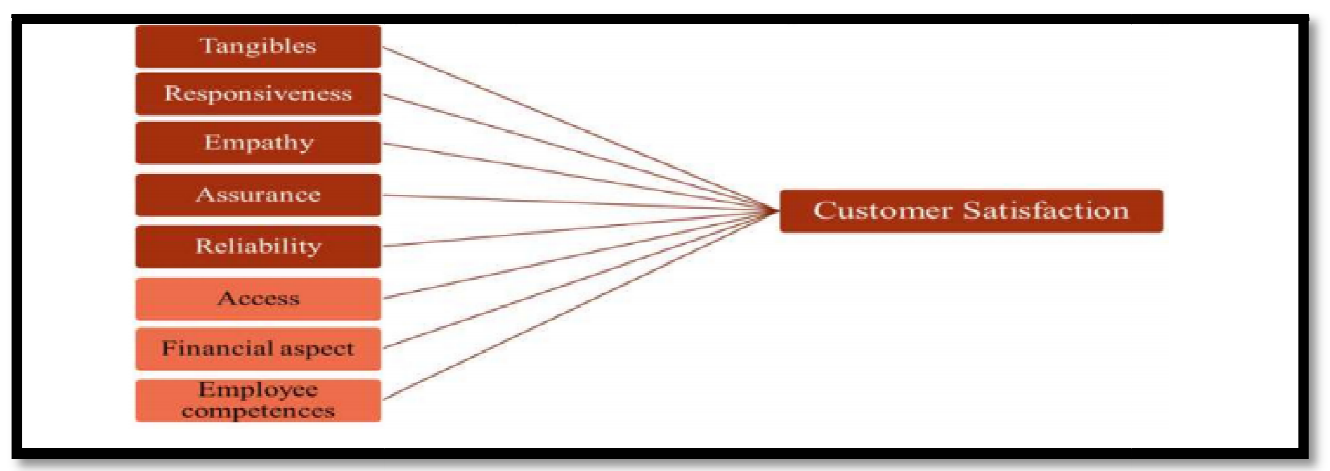

Figure 6: Service Quality and Customer Loyalty (Olah Model, 2018)

The author elaborated that, in this business environment providing quality of the service provided is the important action plan to achieve the goal and success. The framework for determining the quality of the service provided and measuring the gap was developed. The SERVQUAL is an important instrument to determine the quality of the service 
provided and the gap. SERVQUAL is the tool that displayed significantly highest effectiveness in measurement of quality of the service provided.

In an empirical research conducted by Zeithaml et al., (1996) evaluation and achievement of quality of the service provided has been profitable for the business entity owing to various rationales like low priced, customer fidelity and escalated market share. Thus, for measuring the quality of the service provided in Palestinian Islamic banks, one of the researches has applied the most widely used service quality framework namely SERVQUAL. Literature shown that this model using by many authors in different countries to measure the perceived service quality in a considerable time period and at present also using for the empirical studies. In the development process of SERVQUAL framework to improve the quality of the provided service it was using the five attributes, which were discussed above. Even though SERVQUAL framework is subjected to criticism very often, it is the mostly used model to explain service marketing sector. The researchers, who are conducting research studies related to service marketing in countries of United States and Europe region, are using this more often. Evaluations of quality of service in Malaysian Banks done using SERVQAL framework (Cai et al., 2014). The cultural propositions were integrated into the SERVQUAL framework and created the PAKSERV model by Raajpoot using its three attributes: tangibility, reliability, and assurance. Several studies have proved significant relationship of SERVQUAL relationship with customer loyalty (Alnaser et al., 2017).

\subsection{Service Quality}

Service means a non-object that performances cannot be seen, felt, tasted, or touched before an exchange agreement is concluded. The service performance is varied and cannot be stored or reserved for the next use. It cannot divide the Service from provider; it needs the interaction directly between provider and consumer. Felix (2017).

Quality of the service provided takes the stage, and offers more satisfied and loyal customers, and in return, more profit is gained than of competitors. Chun Wang and Zheng Wang, 2006. Presented 22-Items Quality of the service provided scale in the table $\mathrm{xxxx}$ as below.

\begin{tabular}{|c|c|}
\hline Quality of the Service & 22-Item Scale \\
\hline \multirow{5}{*}{$\begin{array}{c}\text { Reliability } \\
\text { (Narteh, 2017, Abdullah } \\
\text { \&Hilmi, 2014). }\end{array}$} & Providing service as promised \\
\hline & Dependability issues related to customer relationship handling \\
\hline & Performing services in the ideal manner at the first effort \\
\hline & Providing services at the promised time \\
\hline & Maintaining error-free record \\
\hline \multirow{5}{*}{$\begin{array}{c}\text { Responsiveness } \\
\text { (Chun Wang And Zheng } \\
\text { Wang, 2006). }\end{array}$} & $\begin{array}{l}\text { Informing the customer about the times of service will be } \\
\text { happening }\end{array}$ \\
\hline & Prompt service to customer \\
\hline & Willingness to help customers \\
\hline & $\begin{array}{l}\text { Staying ready to react quickly according to the requests of the } \\
\text { customers }\end{array}$ \\
\hline & Employees will instill confidence in customers \\
\hline \multirow{4}{*}{$\begin{array}{c}\text { Assurance } \\
\text { (Felix, J Bus Fin Aff 2017; } \\
\text { Olah, 2018) }\end{array}$} & Giving a sense of safety to the customer during the transactions \\
\hline & Employees being courteous in a consistent and continuous manner \\
\hline & Employees acquire the required knowledge to respond the inquiries \\
\hline & customers' questions \\
\hline \multirow{5}{*}{$\begin{array}{c}\text { Empathy } \\
\text { (Chun Wang And Zheng } \\
\text { Wang, 2006). }\end{array}$} & Giving customers individual attention \\
\hline & $\begin{array}{l}\text { Employees should be caring and responsive towards the customer } \\
\text { when they are in contact }\end{array}$ \\
\hline & Focused on the customer's best interests \\
\hline & Employees who understand the needs of their customers \\
\hline & Convenience business hour \\
\hline \multirow{4}{*}{$\begin{array}{c}\text { Tangibles } \\
\text { (Fitzsimmons And } \\
\text { Fitzsimons, 2014; Landhari } \\
\text { Et Al., 2011) }\end{array}$} & Modern equipment \\
\hline & Visually appealing facilities \\
\hline & Employees who have a neat, professional appearance \\
\hline & Visually appealing materials associated with the service \\
\hline
\end{tabular}

Table 1: Items of Service Quality of the Provided Scale

At present service providers in this highly competitive market are demanded to find ways to attract new customers, retain existing customers, and pursue customers' loyalty. When customers are provided with a service, its quality is said to be a determining factor for the progress of the service provider. It is evident to the relationship with the customer satisfaction and success of the service provider (Dyah et al., 2016).

Olah (2018) is the selected model based on the initial model created by Parasuraman et al (1992) and these authors introduced the comprehensive SERVQUAL framework to the different disciplines. At the outset that model consisted of 10 dimensions, which further brought down to five dimensions namely, tangible, reliable, ability to assure, empathetic and being responsive are considered to be the five core aspects of SERVQUAL framework. The SERVQUAL model is a multiple-item measure that can be used to identify customer perceptions and service expectations. It is 
considered to be reliable and valid for evaluating quality of the service provided in a number of trending industrial sectors. During the path to deriving SERVQAL scale Parasuraman et al. (1992) collected empirical data from a divergent range of industries including maintenance and renovation companies, extended distance telecommunication, safety, retail banking, brokerage and credit cards. It has presented ten different elements through SERVQUAL framework, to evaluate the quality of service provided.

The attribute of tangibility, can be explained in the sense of physical characters, personal, tools and communication material. The propensity to perform a given service in a dependable manner with accuracy is called as reliability. The employees' ability to promote confidence and trust being the courtesy of them is referred to as Assurance (Felix, J Bus Fin Aff 2017; Olah, 2018). During the service is provided to the customer, concentrate fully on them and leading the customer willingly by the employee is explained by the phrase Responsiveness (Chun Wang and Zheng Wang, 2006). While delivering a particular service to the client, paying complete attention to the customer is called Empathy (Chun Wang and Zheng Wang, 2006). Several scholars have documented some restraints of the SERVQUAL model and presented alternative models to measure quality of the service provided; Brady and Cronin, 2001; Ladhari, 2008). These academics criticized SERVQUAL because quality of the service provided perception is contingent on numerous unique factors that are industry specific; hence, no single measurement model universally applies across industries.

\subsection{Customer Loyalty}

Among the diverse range of definitions given for 'customer loyalty, some are elaborating on the behavioral attributes taken forward by the consumer, where the returning behavior is described by 'repurchasing behavior. Customer loyalty can be defined as the first step of the repurchasing behavior of customers. Customer fidelity has usually been expressed as a sequel of the experiences that a customer obtained about a service/product provider. The experiences might include tangible elements, connectivity to the feelings, and value chain moments, as discussed in the study conducted by Mascarenhas et al. (2006). When it comes to the consumer's loyalty it is a strategic approach that can elevate customer retention of the business while cutting down the costs of marketing. In a Case Study conducted in Spain noticed the fidelity of the customer for a brand has a positive implication in that services' economic as well as market performance. Loyalty in service businesses refers to the customer's commitment to do business with a particular organization, purchasing their products repeatedly and recommending others to the organization's products. The returning customer, who returns as a result of the impressive service received from the firm, is called as 'Customer loyalty'. Through effective application of loyalty strategy in an appropriate manner it assists in retaining the customer without spending much on product or services marketing (Stan et al., 2013). In the research of Pasha and Waleed (2016), they have stated that acquired value, the reputation of the brand and quality of the service provided alter the satisfaction level of the customer as per the evidence collected from Pakistani Banking experiences. Few authors have studied on perceived quality of the service and customer contentment, which possess a significant impact on Saudi customer loyalty, and reviewed several research publications that investigated the connections among the described attributes. explained that behavioral intensions are carried out to measure the customer loyalty. Customer Loyalty means the connectivity between the respective attitude toward a firm (service) and patronage behavior. Loyalty involves a psychological bond to the service provider and means you are at a certain high degree of customer satisfaction and commitment

Attitudinal loyalty reflects a situation whereby different feelings create an individual's overall attachment to a product, service or organization (Yee, Yeung, and Cheng, 2010). In the case of loyalty of the customer, the earlier research has suggested a divergent number of proposals. As per findings of Yee, Yeung, and Cheng (2010) employees' fidelity, quality of the service provided, and contended satisfied customers contribute a positive attitudes vibe over on customer loyalty in a high-contact service trade. This reflects the degree to which attitudinal feelings are translated into loyalty behavior. In other words, it reflects intentions being translated into actions. Examples of loyalty behaviors given in the literature include continuing to purchase services from the same supplier, increasing the scale and scope of a relationship, or the act of recommending a product or service (Best, 2009). This is an essential fact which can be utilized effectively in building up reliability of the service and its quality). The product or the service price also has become a decision factor as the affordable product price are a cause, which determines the customer loyalty. From a behavioral perspective, loyalty is usually defined in terms of a purchase measure over a specific time period. Still no instrument is developed to evaluate the accurate acquired service value and therefore the customer's decision to purchase is not yet supported with evidence. Some of the research reviewers highlighted that it is a value that is to be evaluated in a non-monetary measuring scale. Literature noted that both attitude and behavior concepts in loyalty should be addressed in a composite approach to eliminate the consequences or drawbacks that can occur by addressing these individually (Chi, 2005). Bennett has described this measurement is oscillating between the single dimensional and two-dimensional duality of loyalty. In many research studies published related to this particular topic, the researcher has confirmed that this implies a positive vibe on perceived quality of the service provided on loyalty of the customer in banking industries elaborated. They have concluded that the quality of service has an influence on loyalty of the customer.

As per the research, findings brought up by Teas (1994) suggest that long-term relationship and customer satisfaction can build by providing high quality of the service provided to customers. In banking industry, a study explained that strong relationship between banks and customers builds customer loyalty, which give competitive advantage to banks. According to the experiences of the practitioners who are in the field the quality of the service provided can be improved firm performance respectively Kashif, Abdur and Pileliene (2016). Earlier research findings have stated that quality of the service provided in the banking sector affects customer satisfaction in a positive manner. Furthermore, considerable amount of work has been done in service industry in order to understand the quality dimensions of the service provided and satisfaction of customers. Rapid rise in financial sectors has provided alternatives 
to customers. The quality of the service provided has played an extensive role in rising up the sales profit, market share, development of good image, and to provide competitive advantage.

\section{Methodology}

The research approach and the research instruments in search of the research objectives and research questions are leads by the research procedure. Due to the theoretical effect Service Quality has with Customer Loyalty in State Banks, the construct of Service Quality is chosen as the independent variable in the literature (Olah, 2018) and Service Quality is claimed to be a vital measure of many factors with results (Gilbert and Wong, 2003; Raza et al., 2020). Therefore, this study analysis is based on the proposed model of SERVQUAL of Olah (2018) and based models from Parasuraman, (1988) along with empirical views where the independent variable was SQ. Hence, SQ is considered as the independent variable of this study.

\subsection{Theoretical Framework}

The basic objective of this study is to study the relationship between service quality and customer loyalty. The independent variables considered in the explanation of service quality are the five identified characteristics. The hypotheses that all those attributes have a positive impact on the quality of the service. This section presents a diagrammatic illustration of the theoretical framework. The conceptual model was developed following various empirical and theoretical studies. In a diagrammatic format, it shows the predictor variable, the five service quality dimensions, namely, tangibles, reliability, responsiveness, assurance, and empathy, whereas the customer loyalty will be the dependent variable. The conceptual Model guiding this study presented in Figure 7.

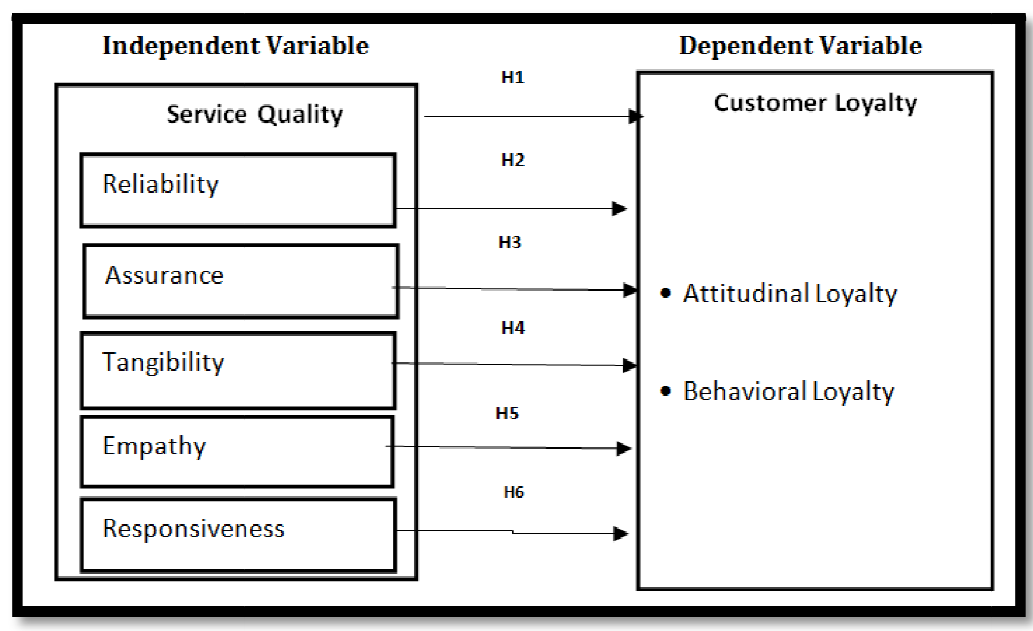

Figure 7: Conceptual Framework

Source: (Olah, 2018; Parasuraman, 1992)

Literature emphasize that Service Quality is taken as essential needful of the customers and research were based with theories of quality. There are many theoretical views such as economic, sociological, education, innovation, psychological, achievement, status withdrawal, social change, social behaviors, leadership, personality and huge empirical work (Olah, 2018, Wang, 2003) which explains the means by which Service Quality has an association between the CL in the banking industry in literature.

The extant literature, has illustrated that Service Quality comprising of five dimensions (Gilbert and wotson, 2003; Parasuraman, 1992; Olah, 2018), CL having two dimensions (Gilbert and wotson, 2003) whereas these variables have not been tested earlier in a single model to examine the association between Service Quality and Customer Loyalty. The Conceptual framework showed the impact of the perceived service quality on customer loyalty. Based on the literature the following hypotheses are formulated.

The formulations of hypotheses were based on the literature review, the research objectives and research questions as represented in the conceptual framework of this study. The hypothesis one is formulated based on the first objective of the study as given in table 2 .

\begin{tabular}{|c|c|}
\hline Research Objective:1 & $\begin{array}{c}\text { To investigate the relationship between Service Quality and Customer } \\
\text { Loyalty in the State Development Bank in the Kaluthara District }\end{array}$ \\
\hline Research Question:1 & $\begin{array}{c}\text { What is the association between Service Quality and Customer Loyalty } \\
\text { in the State Development Bank in the Kaluthara District? }\end{array}$ \\
\hline Hypothesis 1 & $\begin{array}{c}\text { H1: There is an association between Service Quality and Customer } \\
\text { Loyalty in the STATE BANKS in the Kaluthara District }\end{array}$ \\
\hline
\end{tabular}

Table 2: Hypotheses for the Objective One 
Hypothesis two was developed with 5 sub dimensions of Service Quality. There are five individual hypotheses based on the association of each of the five different dimensions of Service Quality and Customer Loyalty. The hypothesis two to six were generated based on the second objective and second question of the study are presented in table 3

\begin{tabular}{|l|l|}
\hline Research Objective: 2 & $\begin{array}{l}\text { To assess the relationship between dimensions of Service Quality } \\
\text { and Customer Loyalty in the State banks in the Kaluthara District }\end{array}$ \\
\hline Research Question: 2 & $\begin{array}{l}\text { How do the relationships between dimensions of Service Quality and } \\
\text { Customer Loyalty in the State Banks in the Kaluthara District? }\end{array}$ \\
\hline Hypotheses: 2 to 6 & $\begin{array}{l}\text { H2: There is a relationship between Service Reliability and customer } \\
\text { loyalty in the State Banks in the Kaluthara District } \\
\text { H3: There is a relationship between Service Assurance and Customer } \\
\text { Loyalty in the State Banks in the Kaluthara District } \\
\text { H4: There is a relationship between Service Tangibility and } \\
\text { customer loyalty in the State Banks in the Kaluthara District } \\
\text { H5: There is a relationship between Service Empathy and Customer } \\
\text { Loyalty in the State Banks in the Kaluthara District } \\
\text { H6: There is a relationship between Service Employee } \\
\text { Responsiveness and Customer Lovalty in the State Banks in the }\end{array}$ \\
\hline
\end{tabular}

Table 3: Hypotheses for the Objective Two and Question Two

Research design is a framework drawn by the researcher explaining the way of collecting and analyzing data so that the research questions can be properly answered. Research design process consists of design in research philosophy and research approach, research paradigm, research design method, justification and type of data. Based on the Onion model of Saunders et al., (2016), it is highlighted several stages in the research design process to this study. Elements of Research Design involved in the study: Purpose of the study is hypotheses testing, Researcher interference is Minimal, Study setting is non-contrived (field study), Unit of analysis is organization and Time horizon is cross sectional (Sekaran and Bougie, 2013). Sampling design process expressed the views that the population number is 12700 of customers in the four branches in Sate Banks in Kaluthara. Out of this population, this study planned to gathered data from 384 customers. Anyhow, with the pandemic situation in the country only could collected data from the 256 customers.

$$
n=\frac{N}{1+N(e) 2}
$$

Where $\mathrm{n}=$ Sample size, $\mathrm{N}=$ Accessible population and $\mathrm{e}=$ Level of significance at 0.05 .

Reliability and validity of the instrument in order to reduce the possibility of getting the wrong answer, attention was paid on the reliability and validity of the questionnaire. Numbers of different steps were taken to ensure the validity and reliability of the study: Data were collected from the reliable sources.

In order to validate and refine the questionnaire prior to administering the main survey, the pilot survey was carried out by administering the questionnaire to a sample of 32 of customers in the State Banks in the Kaluthara District.

Before performing the final test, the researcher conducted a pre-test and a pilot study to measure the validity and reliability of the data set collected through the questionnaire. Four Branches in State Banks customers in the Kaluthara district were randomly selected to conduct a pilot survey to appraise an applicable, accurate and relevance questionnaire. Finally, the fine-tuned questionnaire was distributed among 256 State Banks bank customers in the Kaluthara district. Sample Adequacy of the Pilot Test presents in the table 4.

\begin{tabular}{|c|c|c|}
\hline Variables & Kaiser-Meyer-0lkin Measure & Bartlett's Test Significant Value \\
\hline Service Reliability & 0.789 & 0.000 \\
\hline Service Assurance & 0.766 & 0.000 \\
\hline Service Tangibility & 0.750 & 0.000 \\
\hline Service Empathy & 0.802 & 0.000 \\
\hline Employee Responsiveness & 0.824 & 0.000 \\
\hline Attitudinal Loyalty & 0.796 & 0.000 \\
\hline Behavioral Loyalty & 0.787 & 0.000 \\
\hline
\end{tabular}

Table 4: Sample Adequacy of the Pilot Test

Reliability means the ability to generate a stable and consistent evaluation of an instrument. Cronbach's alpha is the well-known coefficient which measures the internal consistency of data while deciding how the items relate to each other on the test. Besides, reliability demonstrates how much the research study is free from bias and guarantee the consistent for the time. To get the results more reliable, collected responses should be consistent. The higher value of consistency means the data was more reliable. Cronbach's Alpha coefficients which were above 0.7 is accepted in social sciences as reliable of the instruments (Nyumba et al., 2015).Cronbach's Alpha test is conducted for this study and the results are presented in Table 3.6 below. All the results are above 0.7 and it indicates that collected data has a relatively high degree of internal consistency to conduct the research study. Table 5 presented Reliability of the Pilot Test as follows. 


\begin{tabular}{|c|c|c|}
\hline Variables & Reliability Cronbach's Alpha $>\mathbf{0 . 7}$ & Number of Questions \\
\hline Service Reliability & 0.938 & 6 \\
\hline Service Assurance & 0.905 & 6 \\
\hline Service Tangibility & 0.735 & 5 \\
\hline Service Empathy & 0.955 & 6 \\
\hline Employee Responsiveness & 0.844 & 6 \\
\hline Attitudinal Loyalty & 0.983 & 6 \\
\hline Behavioral Loyalty & 0.972 & 6 \\
\hline
\end{tabular}

Table 5: Reliability of the Pilot Test

The data analysis process continues in the final test using the complete sample of 256 customers in State Banks in Kaluthara district. Next, the reliability and validity of the instrument is analyzed.

\section{Findings and Discussion}

After clearing the data set, there were 244 data. The preceding chapter presented the hypothesis and research questions along with choice and rationale of the research approaches adopted for this study. Data must be screened in order to ensure the data is useable, reliable, and valid for testing causal theory. According to Anesthesiol(2013), missing data (or missing values) is defined as the data value that is not stored for a variable in the observation of interest. The problem of missing data is relatively common in almost all research and can have a significant effect on the conclusions that can be drawn from the data. Accordingly, some studies have focused on handling the missing data, problems caused by missing data, and the methods to avoid or minimize such in medical research. Missing data present various problems. First, the absence of data reduces statistical power, which refers to the probability that the test will reject the null hypothesis when it is false. Second, the lost data can cause bias in the estimation of parameters. Third, it can reduce the representativeness of the samples. Fourth, it may complicate the analysis of the study. Each of these distortions may threaten the validity of the trials and can lead to invalid conclusions. It also known as data cleansing, Data wash and scrubbing. Data cleaning involves the detection and removal (or correction) of errors and inconsistencies in a data set or database due to the corruption or inaccurate entry of the data. Incomplete, inaccurate or irrelevant data is identified and then either replaced, modified or deleted. Incorrect or inconsistent data can create a number of problems which lead to the drawing of false conclusions. Therefore, data cleaning can be an important element in some data analysis situations. However, data cleaning is not without risks and problems including the loss of important information or valid data. SPSS statistical tool used to support data cleaning, which can pick up some errors automatically, for example, non-valid variable codes. As a result of data cleaning effort, questionnaire with 42 questions were reduced to 39 questions when analyzing them. Based on the sample of 244 frequency analysis of the respondents by their demographic information.

According to the central limit theorem, it can be assumed that the data set is an approximately normally distributed if the data set has more than 30 sample and it describe as a large sample (Kwak \& Kim, 2017). Descriptive analysis has provided separately for each independent variables, Reliability, Assurance, Tangibility, Empathy, Employee Responsiveness and the dependent variable, Customer Loyalty.

\subsection{Reliability and Validity Test}

The reliability of a research ensures the consistency of the data set where validity refers the accuracy of a measure. It states whether the results really represent what they are supposed to measure. By using Cronbach's alpha value consistency of the data set can be measured. However, the general rule of the Cronbach's alpha is if the value is above 0.7 it can be considered as reliable data. It is better to have values closer to 1 to have higher internal consistency. Reliability Test with Cronbach's Alpha Value for Reliability is 0.950, Assurance is 0.935, Tangibility is 0.911, Empathy is 0.935, Employee Responsiveness is 0.947. and Dependent variable is 0.992 respectively. Based on the Cronbach's Alpha values of both the independent variables and the dependent variable is greater than 0.7 and close to 1 . The required Cronbach's Alpha level satisfied. Therefore, it can be said that the data are reliable.

\subsubsection{Factor Analysis}

Factor analysis attempts to bring correlated variables together under more general, underlying variables. The purpose of factor analysis is to reduce many individual items into a fewer number of dimensions. Factor analyses offers not only the possibility of gaining clear understanding of the gathered data, but also the possibility if using the output in subsequent analyses. KMO and Bartlett's Test Value for the Reliability is 0.855 with sig value of 0.000 , Assurance is 0.839 with sig value of 0.000 , Tangibility is 0.775 with sig value of 0.000 , Empathy is 0.916 with sig value of 0.000 , Employee Responsiveness is 0.847 with sig value of 0.000 , and Customer Loyalty is 0.943 with sig value of 0.000 respectively. All factor loading values indicated that greater than 0.5 . The KMO values of each variable to measure the sampling adequacy. KMO values should be greater than 0.5 and significance of the Bartlett's Test of Sphericity should be less than 0.05 level of significance to consider as valid data. All the variables were satisfying the required level of adequacy. Based on the information this study can be concluded that, all the indicators and dimensions that are used to develop the construct is soundly valid.

\subsubsection{Descriptive Analysis}

This analysis is steered to comprehend the distribution of the responses related to each item as well as for each construct of the study. In this study to define them, the central tendency measures and the dispersion measures were 
calculated and lastly the normality test of the data set were obvious using central large sample approximation and central limit theorem. Based on the central limit theorem, it can be expected that the data set is an approximately normally distributed, if the data set has more than 30, it can be described as a large sample (Kwak \& Kim, 2017). The summary of the descriptive analysis presented in the table 6.

\begin{tabular}{|c|c|c|c|c|c|}
\hline & Mean & Median & Mode & Std. Deviation & Variance \\
\hline Reliability & 3.8654 & 4.0000 & 4.00 & 0.62981 & 0.397 \\
\hline Assurance & 3.8777 & 3.8333 & 4.00 & 0.60232 & 0.363 \\
\hline Tangibility & 2.5318 & 2.7500 & 3.00 & 0.71418 & 0.510 \\
\hline Empathy & 3.9153 & 4.0000 & 4.00 & 0.64123 & 0.411 \\
\hline Responsiveness & 3.6648 & 3.6000 & 3.60 & 0.71497 & 0.511 \\
\hline Loyalty & 3.8589 & 4.0000 & 4.00 & 0.71122 & 0.506 \\
\hline
\end{tabular}

Table 6: Summary of the Descriptive Analysis

The Table 6 signifies the descriptive statistics of all variables, which have mean value while median, and mode values. It indicates that the overall response to the variable is agreed. The standard deviation and variance are highlighted. The range is indicated under minimum and the maximum respectively values. Finally, the skewness and kurtosis are mentioned, which implies that the data set is positively skewed showing a flat distribution.

\subsection{Inferential Statistics}

The inferential statistical analysis conducted to assess the acceptability of the sample parameter into population parameters. As well as the outcome of the inferential analysis is used to test the hypotheses. Correlation analysis is key statistical analysis which is used for this analysis.

\subsubsection{Correlation Analysis}

Pearson correlation relationship between Reliability and Customer Loyalty presented the value as $0.874^{* *}$ with the sig value 0.000 . Assurance and Customer Loyalty presented the value as $0.874^{* *}$ with the sig value 0.000 . Tangibility and Customer Loyalty presented the value as $0.210^{*}$ with the sig value 0.000 . Empathy and Customer Loyalty presented the value as $0.918^{* *}$ with the sig value 0.000 and Employee Responsiveness and Customer Loyalty presented the value as $.895^{* *}$ with the sig value 0.000 respectively. Therefore, it can be concluded that except one dimension with a significant positive and weak relationship namely Tangibility and other for dimensions have significant positive and strong correlation to customer loyalty of state banks. Further, Pearson Correlation relationship between Service Quality and Customer Loyalty is presented as the value of $.901^{* *}$ with the sig value of 0.000 . According to that the correlation between service quality and customer loyalty is significant because the significance value 0.000 is less than 0.05 level of significance. As well as the Pearson correlation is 0.901 and it is a strong positive correlation. Therefore, it can be concluded that service quality has significant positive and strong correlation to customer loyalty of the banks.

\subsection{Hypotheses Testing}

The hypotheses testing is conducted to analysis significance of the impact of each variable on dependent variable and correlation analysis is used to check the significant of the association between the Service Quality and the Customer Loyalty. Hypotheses indicate in the table 7.

\begin{tabular}{|c|c|c|}
\hline Hypotheses & Decision Criteria & Decision \\
\hline $\begin{array}{l}\text { H1: There is a relationship between Service Quality } \\
\text { and Customer Loyalty in the state banks in the } \\
\text { Kaluthara District }\end{array}$ & $\begin{array}{l}\text { Pearson Correlation } \\
0.901 \\
\text { P-Value }-0.000\end{array}$ & Accepted \\
\hline $\begin{array}{c}\text { H2: There is a relationship between Service Reliability } \\
\text { and Customer Loyalty in the state banks in the } \\
\text { Kaluthara District }\end{array}$ & $\begin{array}{c}\text { Pearson Correlation } \\
0.874 \\
\text { P-Value }-0.000\end{array}$ & Accepted \\
\hline $\begin{array}{l}\text { H3: There is a relationship between Service Assurance } \\
\text { and Customer Loyalty in the state banks in the } \\
\text { Kaluthara District }\end{array}$ & $\begin{array}{c}\text { Pearson Correlation } \\
0.874 \\
\text { P-Value }-0.010 \\
\end{array}$ & Accepted \\
\hline $\begin{array}{c}\text { H4: There is a relationship between Service } \\
\text { Tangibility and Customer Loyalty in the state banks in } \\
\text { the Kaluthara District }\end{array}$ & $\begin{array}{c}\text { Pearson Correlation } \\
0.210 \\
\text { P-Value }-0.000 \\
\end{array}$ & Rejected \\
\hline $\begin{array}{c}\text { H5: There is a relationship between Service Empathy } \\
\text { and Customer Loyalty in the state banks in the } \\
\text { Kaluthara District }\end{array}$ & $\begin{array}{c}\text { Pearson Correlation } \\
0.918 \\
\text { P-Value }-0.000 \\
\end{array}$ & Accepted \\
\hline $\begin{array}{c}\text { H6: There is a relationship between Employee } \\
\text { Responsiveness and Customer Loyalty in the state } \\
\text { banks in the Kaluthara District }\end{array}$ & $\begin{array}{c}\text { Pearson Correlation } \\
0.895 \\
\text { P-Value }-0.000\end{array}$ & Accepted \\
\hline
\end{tabular}

Table 7: Test of Hypotheses 
Based on the results of the Pearson Correlation, all the hypotheses were accepted, which means, service reliability, service assurance, service tangibility, service empathy and employee responsiveness have significant association with customer loyalty in the state banks in the Kaluthara District. As well as the overall Service Quality is also significantly association with Customer Loyalty in the state banks in the Kaluthara District. Above finding were discussed and concluded as well as provided appropriate recommendation through literature.

\section{Discussion}

Both the research questions were used by the findings of the analysis. According to that, the association between Service Quality on Customer Loyalty of State Banks in the Kaluthara district, Sri Lanka is significant as well as Service Quality has a significant relationship on Customer Loyalty.

Individual dimensions of Service Quality on Customer Loyalty of state Bank in the Kaluthara District, Sri Lanka has different level of association. Service empathy and employee responsiveness have strong relationship than service reliability and service assurance. Also, the tangibility has no significant relationship on customer loyalty in the state Banks in the Kaluthara district. Above findings were discussed and concluded as well as provided appropriate recommendations through literature evidence. According to the given information, all the hypotheses were accepted except the association between service tangibility and customer loyalty. Therefore, service reliability, service assurance, service empathy and employee responsiveness have significant relationship on customer loyalty in the state banks in the Kaluthara district. Further, the overall service quality also significantly relationship between customer loyalty in the state banks in the Kaluthara district.

Prior to conduct the inferential statistic analysis, it was measured the key prerequisites to conduct the study. According that the central limit theorem proved that the responses for each variable can be assumed as a normally distributed, and the reliability and validity assumptions are in acceptable level. The inferential statistical analysis conducted to assess the acceptability of the sample parameter into population parameters. As well as the outcome of the inferential analysis is used to test the hypotheses. Correlation analysis and the regression analysis are key statistical analysis which is used for this analysis. The main reason of conducting correlation analysis is, there must be a significant relationship between independent and dependent variables prior to conduct the regression analysis. All the relationships between independent variables and the dependent variable were strong relationships except the relationship between service tangibility and the customer loyalty. The relationship between service tangibility and the customer loyalty is a weak relationship and does not show a significant. The simple regression analysis output proved that the significant and strong impact of service quality on customer loyalty and multiple regression analysis proved that significant impact of each independent variable on dependent variable except the service tangibility.

According to the results of regression analysis, all the hypotheses were accepted except the impact between service tangibility and customer loyalty. Which means, service reliability, service assurance, service empathy and employee responsiveness have significant impact on customer loyalty in the State banks in the Kaluthara District. As well as the overall service quality is also significantly impact on customer loyalty in the State Banks in the Kaluthara District.

In the qualitative data analysis, it was identified five themes such as Service reliability is an essential component of a customer loyalty in the state banks in the Kaluthara district of Sri Lanka. Service assurance is a vital component of a customer loyalty in the banks in the Kaluthara district of Sri Lanka, Service tangibility too is an indispensable component of a customer loyalty in the state bank in the Kaluthara district of Sri Lanka, Service empathy also play an important role and is a vital component of a customer loyalty in the State bank in the Kaluthara district of Sri Lanka and Employee responsiveness too is recognized as an crucial component of a customer loyalty in the state banks bank Kaluthara district of Sri Lanka. Based on their themes, it was identified that Service reliability, service assurance, service tangibility, service empathy and employee responsiveness are essential component of a customer loyalty in the State Banks in the Kaluthara district of Sri Lanka. According to those findings, it was found that the service tangibility has positive impact with customer loyalty in banking industry, but it was not significant related to the state Banks. According to the research findings, it was found that the qualitative and quantitative findings are compatible and service quality mattered to the customer loyalty in the State Banks in the Kaluthara District.

\section{Conclusion and Recommendations for Future Research}

This investigation can be simulated in the similar manner with a large respondent size and more different types of variables build the relationship between the loyalty of a customer towards its state banks. This research study summarized that Customer Loyalty is important but not that much applicable service tangibility in banking sector of Sri Lanka, hence future researches can be contributed on how banks can improve the technology-based activities for their valued customers.

The service reliability should be increased and maintained to achieve better customer loyalty. In order to do that the banks need to identify and rectify any errors in the service delivery, the bank need to gain accuracy in the banking system. State bank personals should have the knowledge to answer the questions of the customers, bank needs provide services as promised, bank prioritizes and analyzes the debt financing requirements fairly, bank need to implement favorable lending terms and fair interest rate for debt financing to reduce defaults on payment. In that sense, the bank should train the employee frequently to improve their skills and update their knowledge. As well as they should improve their service reliability with the customer suggestions.

The service assurance is a highly concerned factor by the customer and to confirm the level of service assurance, it should create a safe feeling in transaction with banks, employees need to give confidence to all transactions, keeping clients' data confidentiality, banks should achieve the client requirement and there should be a minimum qualifications 
when prioritizing and analyzing the loan. In that sense, bank should improve their current of banking service with the updated service regulations of the banking industry.

The service tangibility is an important aspect of the current banking industry. Even there is a better customer loyalty of the bank, they should work on acquire modern equipment and advanced technologies to improve the banking service with higher efficiency. Otherwise, it is difficult to survive and maintain the current level of customer loyalty in long-lasting future.

Customer empathy is one of significant aspect to create a better customer loyalty. In order to do that the bank should give individual attention to customer, deal Customer with care understand the need of customer, bank and the employee should have problems solving attitude, need to locate branches in convenient location and need to create trustworthy feeling in the mind of customer about banking services. In that sense, the bank should improve their customer service with proper and professional training curriculum.

The employee responsiveness is another important aspect of the customer loyalty, and the bank has provided prompt and quick service willing to help customers, ready to response quickly, always keep customers informed and reduced waiting time in queues. To further improve their system the banks should make proper system to customer handling with increasing counters and adding lasted technologies.

\section{References}

i. Ahmad, S. Z., Xavier, S. R. and Bakar, A. R. A. (2014).'Examining entrepreneurial intention through cognitive approach using Malaysia GEM data'. Journal of Organizational Change Management,27(3), 449464.https://doi.org/10.1108/JOCM-03-2013-0035.

ii. Ahmed, Z. U., and Zgheib, P. W., Carraher, S., and Kowatly, A. K. (2013). Public policy and expatriate entrepreneurs. Journal of Entrepreneurship and Public Policy, 2(1),4253. https://doi.org/10.1108/20452101311318666.

iii. Alhkami and Alarussi, (2016), Service Quality Dimensions and Customer Satisfaction in Telecommunication Companies in Yemen, March 2016

iv. [Al-msallam, S. (2015). The Relationship between Customer Satisfaction and Customer Loyalty in the Banking Sector in Syria. Journal of Marketing and Consumer Research, 7.

v. Alnaser, F., Ghani, M., \&Rahi, S. (2017). The Impact of SERVQUAL Model and Subjective Norms on Customer's Satisfaction and Customer Loyalty in Islamic Banks: A Cultural Context. Int J Econ ManagSci, 6(5), 455.

vi. Al-Rousan et al., (2010), International Journal of Human and Social Sciences 5:13 2010

vii. An, Noh, (2009) Airline customer satisfaction and loyalty: impact of in-flight service quality

viii. Annual Report (2011), Empowering Sri Lankan, Sri Lankan PradhesiyaSanwardene Bank

ix. Annual Report (2019), Invested in Changing, Regional Development Bank

x. Auh\& Johnson, (2005). 25 Cognitive, Affective, and Attribute Bases of the Satisfaction Response

xi. Bahadori, (2015), University Utara Malaysia, Kedah, Malays Factors affecting dental service quality. MohammadkarimBahadori ${ }^{1}$, Mehdi Raadabadi, RaminRavangard, DoniaBaldacchino, Affiliations expand, PMID: 26241090, DOI: 10.1108/IJHCQA-12-2014-0112

xii. Bakar H O, Sulong Z (2018) The Role of Financial Sector on Economic Growth: Theoretical and Empirical Literature Reviews Analysis. J Glob Econ 6: 309 -

xiii. Bakar, H.O., \&Sulong, Z. (2018). The Role of Financial Sector on Economic Growth: Theoretical and Empirical Literature Reviews Analysis. J Glob Econ, 6: 309.

xiv. Bandara, C. (2016), January 04). What causes SMEs to fail in Sri Lanka? Retrieved from http://www.dailymirror.lk/101755/what-causes-smes-to-fail-in-sri-lanka

xv. Bashir Ahmad Fida (2018), Modern College of Business \& Science, PC 133, Muscat, Oman. Email: bashir@mcbs.edu.om

xvi. Best, R. (2009). 'Market-Based Management: Strategies for growing customer value and profitability'. $5^{\text {th }}$ edition. Pearson, Prentice Hall.

xvii. Central Bank Annual Report (2019), The Central bank of Sri Lanka,

xviii. Chavan, J., \& Ahmad, F. (2013). Factors Affecting on Customer Satisfaction in Retail Banking: An Empirical Study. International Journal of Business and Management Invention, 2(1), 55-62.

xix. Cheng-Lung (2005), Investigating the effects of airline service quality on airline image and passengers' future behavioral intentions: findings from Australian international air passengers.

xx. Chi, G. (2005), A study of developing destination loyalty model. Doctor of Philosophy, Human Environmental Sciences, College of the Oklahoma State

xxi. Chi, G. (2005). A Study of Developing Destination Loyalty Model. Doctor of Philosophy Dissertation, Oklahoma State University. (UMI No. 3181663).

xxii. Chun Wang and Zheng Wang, (2006). The role of relationship quality and loyalty programs in building customer loyalty, Journal of Business \& Industrial Marketing ahead-of-print(ahead-of-print), DOI:10.1108/JBIM-02-20190093

xxiii. Dhandabani, S. (2010). Linkage between service quality and customers loyalty in commercial banks. International Journal of Management \& Strategy, 1 (1), 1-22.

xxiv. Dharmaratne, G. D. I. K., (2014). An Empirical Investigation on the Internet Banking Service Quality and Its Impact on Customer Satisfaction and Loyalty: Special Reference to the Sri Lankan Banking Sector (Dissertation for PhD). Management and Science University, Malaysia 
xxv. Dowling, G. and Uncles, M. (1997) Do Customer Loyalty Programs Really Work? Sloan Management Review, 38, 71-82.

xxvi. Egan, J. (2004), Relationship marketing: Exploring relational strategies in marketing (2nd eds.). Harlow: Pearson Education Ltd.

xxvii. Eugenia Petridou, CharalambosSpathis, and NikiGlaveli, (2007), Bank service quality: Empirical evidence from Greek and Bulgarian retail customers, International Journal of Quality \& Reliability Management 24(6):568-585, July 2007. DOI:10.1108/02656710710757772

xxviii. Felix R (2017). Service Quality and Customer Satisfaction in Selected Banks in Rwanda. J Bus Fin Aff 6: 246. doi: 10.4172/2167-0234.1000246

xxix. Fida1, Ahmed, Al-Balushi1 \& Singh, (2020). Impact of Service Quality on Customer Loyalty and Customer Satisfaction in Islamic Banks in the Sultanate of Oman First Published May 122020 Research Article https://doi.org/10.1177/2158244020919517

xxx. Gamage, B. N. (2014). Entrepreneurship orientation, business performance appraisal of small and medium scale enterprises : Reference to Hambanthota district, Sri Lanka. International Journal of Marketing, Financial Services and Management Research, 03(12), 174-185.

xxxi. Gambo, M. K. K. (2013), Customer perception of the effectiveness of service quality delivery of Islamic Banks in Nigeria: An evaluation of Jaiz Bank. Journal of Marketing and Consumer Research, 1, pp. 9-16.

xxxii. Gianfranco Walsh, Markus Groth\&Klaus-Peter Wiedmann (xxx), An Examination of Consumers' Motives to Switch Energy Suppliers

xxxiii. Gilbert, D., Wong, R. K. C. (2003), Passenger expectations and airline services: A Hong Kong based study. Tourism Management, 24, pp. 519-532,

xxxiv. Gilberta, ${ }^{*}$, Robin K.C. Wongb Tourism Management 24 (2003) 519-532

xxxv. Gupta \& Bansal, (2012), Development of An Instrument to Measure Internet Banking Service Quality in India.

xxxvi. Gupta, Kamal K; Bansal, Ipshita.Researchers World; Malegaon Vol. 3, Iss. 2 Part 2, (Apr 2012): 11-25. https://creativecommons.org/licenses/by/4.0/(https://creativecommons.org/licenses/by/4.0/) (https://us.sagepub.com/en-us/nam/open-access-at-sage). https://doi.org/10.1002/dir.20049, Citations: 3

xxxvii. iang, Y., \& Wang, C.L. (2006). The impact of affect on service quality and satisfaction: the moderation.

xxxviii. Jamal \&Anastasiadou (2009), Investigating the effects of service quality dimensions and expertise on loyalty, Ahmad Jamal, Kyriaki Anastasiadou, European Journal of Marketing, ISSN: 0309-0566, Article publication date: 3 April 2009

xxxix. Jiang, Y., \& Wang, C.L. (2006). The impact of affect on service quality and satisfaction: the moderation of service contexts. Journal of Services Marketing, 20/4, 211-218. http://dx.doi.org/10.1108/08876040610674562

xl. Jin-Woo, P., Rodger, R., Cheng-Lung, W. (2005), Investigating the effects of airline service quality on airline image and passengers' future behavioral intentions: Findings from Australian international air passengers. The Journal of Tourism Studies, 16 (1), pp. 1-10,

xli. Kashif, M., AbdurRehman, M. and Pileliene, L. (2016), 'Customer perceived service quality and loyalty in Islamic banks: a collectivist cultural perspective', The TQM Journal, 28(1), 62-78.

xlii. Khan, B., \&Rizwan, M. (2014). Factors Contributing to Customer Loyalty in Commercial Banking. International Journal of Accounting and Financial Reporting, 4(2), 413-436. doi:10.5296/ijafr.v4i2.6537

xliii. Ladhari, R., Ladhari, L., and Morales, M. (2011), 'Bank service quality: comparing Canadian and Tunisian customer perceptions', International Journal of Bank Marketing, Vol. 29, No.3, pp. 224-246.

xliv. Moguluwa, S. C., Ode, E. (2013), Evaluating customer perceived service quality and customer satisfaction in the Nigerian Banking Industry. Far East Journal of Psychology and Business, 11 (3), pp. 34-46. Myungsook An, Yonghwi Noh, Published 2009

xlv. Morawakage, P. S., \&Kulathunga, K.M.K.N.S. (2013). The empirical study on customer satisfaction towards service quality of commercial banks in Sri Lanka with a comparison between state banks and private banks. Paper presented at the International Conference on Business and Information (pp. 1-10), Organized by the University of Kelaniya. Colombo, Sri Lanka.

xlvi. Olah, (2018), The Service Quality Dimensions that Affect Customer Satisfaction in the Jordanian Banking Sector, MiklósPakurár, Hossam Haddad, János Nagy, József Popp, JuditOláh

xlvii. Olatokun, W., Nwonne, S. (2012), Determinants of users' choice of mobile service providers in the Nigerian Telecommunications Market. African Journal of Computing \& ICT, 5 (4), pp. 19-32.

xlviii. Pakdil, F., Aydin, 0. (2007), Expectations and perceptions in airline services: An analysis using weighted SERVQUAL scores. Air Transport Research Management, 13, pp. 229-237

xlix. Parasuraman, A., Zeithaml, V. A., Berry, L. L. (1988), SERVQUAL: A multiple item scale for measuring consumer perception of service quality. Journal of Retailing, 64 (1), pp. 12-37

l. Parasuraman, A., Zeithaml, V.A., and Berry, L.L. (1985). 'A Conceptual Model of Service Quality and Its Implications for Future Research,' Journal of Marketing (49:4), Fall85, pp 41-50.

li. Parasuraman, A., Zeithaml, V.A., and Berry, L.L. (1988). 'Servqual: A Multiple-Item Scale for Measuring Consumer Perceptions of Service Quality,' Journal of Retailing (64:1), Spring88, pp 12-40

lii. Pasha, Ahmad and Waleed, Ahmad, (2016). Factors Affecting Customer Loyalty in Banking Sector of Punjab, Pakistan. A Research Journal of Commerce, Economics, and Social Sciences, 2016, 10(2), 43-52.

liii. Phillip E. Pfeifer, (2005), Non-parametric estimation of mean customer lifetime valueHeejung Bang, First published: 19 October 2005, 
liv. Pritchard, M., \&Silvestro, R. (2005). Applying the Service Profit Chain to analyse retail performance: The case of the Managerial Straitjacket? International Journal of Service Industry Management, 16(4), pp. 337-356.

lv. Quan S (2010) The relationships among e-service quality, system quality, information quality and customer loyalty: an empirical study of internet banking in China. Glob J Manag Bus Res 10(7 Ver.1.0):27-34

lvi. Rahim, A. G. (2016). Perceived service quality and customer loyalty: The mediating effect of passenger satisfaction in the Nigerian Airline Industry.

lvii. Ramzi, M. Badaruddin Mohamed (0, Customer satisfaction and loyalty in service: Two concepts, four constructs, several relationships Customer Loyalty and the Impacts of Service Quality: The Case of Five Star Hotels in Jordan Al-Rousan. DOI:10.9756/IAJBM/V5I2/1810028,

lviii. Raza, S.A., Umer, A., Qureshi, M.A. and Dahri, A.S. (2020), 'Internet banking service quality, e-customer satisfaction and loyalty: the modified e-SERVQUAL model', The TQM Journal, Vol. 32 No. 6, pp. 14431466. https://doi.org/10.1108/TQM-02-2020-0019

lix. Rhoades D., Waguespack B. (2004), Service and safety quality in US airlines: Pre- and post-September 11th. Managing Service Quality, 14(4), pp. 307-316. Rhoades and Waguespack, (2004).

lx. Richard L. Oliver (1993), Journal of Consumer Research, Volume 20, Issue 3, December 1993, Pages 418430, https://doi.org/10.1086/209358, Published:01 December 1993,

lxi. Saha, G., Theingi, S. (2009), Service quality, satisfaction, and behavioural intentions: A study of low-cost airline carriers in Thailand. Managing Service Quality, 19(3), pp. 350-372.

lxii. Salazar, A. C., Paulo, R. (2004), Relationship between service quality, customer satisfaction and behavioural intentions: A study on the hospitality sector. Proceedings of the 33 rd EMAC (European Marketing Association Conference), May, 2004 Morcia, Spain.

lxiii. Saunders, M., Lewis, P., and Thornhill, A. (2016). Research methods for business students.7th Edition. London UK: Pearson.

lxiv. SeigyoungAuh (2005), Compatibility effects in evaluations of satisfaction and loyalty, February 2005, Journal of Economic Psychology 26(1):35-57, DOI:10.1016/j.joep.2003.10.002, Arizona State University

lxv. Sein, M., Chey, C.K. (2013), Demographic factors in the evaluation of service quality in higher education: A Structural Equation Model (SEM) approach. International Journal of Marketing Studies; 6(1), pp. 90-102. Sein\&Chey, (2013)

lxvi. Sekaran, U., \&Bougie, R. (2013). Research methods for business: a skill-building approach (6th Ed). New York: John Wiley \& Sons.

lxvii. Smith, A. E., Swinehart, K. D. (2001), Integrated systems design for customer focused healthcare performance measurement: A strategic service unit approach. International Journal of Healthcare Quality Assurance, 14, pp. 21-29.

lxviii. Stan, V., Caemmerer, B., \&Cattan-Jallet, R. (2013). Customer Loyalty Development: The Role Of Switching Costs. Journal of Applied Business Research (JABR), 29(5), 1541-1554. https://doi.org/10.19030/jabr.v29i5.8069

lxix. Suraya A M, Syed S A, Nor R K and Che A C W (2018), The Influence of Relationship Marketing Orientation (RMO) on Customer Retention in Travel Agency Services, December 2018

Ixx. Sureshchandar, G.S., Rajendran, C., Anantharaman, R.N. (2002). The relationship between service quality and customer satisfaction - A factor specific approach. Journal of Service Marketing, 16(4), 363-379.

lxxi. Tsoukatos Graham K. Rand, (2006),'Path analysis of perceived service quality, satisfaction and loyalty in Greek insurance', Managing Service Quality: An International Journal, Vol. 16 Iss 5 pp. 501 - 519 Permanent link to this document: http://dx.doi.org/10.1108/09604520610686746

lxxii. Weerakoon, C. (2014). Organizational Determinants of Entrepreneurial Orientation: (With Reference to Small Scale ITBPO Firms in Sri Lanka). International Journal of Science and Research 3(10):1240-1247.

lxxiii. Wellalage, N. H. (2012). Ownership Structure and Firm Financial Performance: Evidence from Panel Data in Sri Lanka m Journal of Business Systems. Governance and Ethics, 7(1), 52-65.

lxxiv. Wickramaratne, A, Kiminami, A., and Yagi H (2014).Entrepreneurial Competencies and Entrepreneurial Orientation of tea Manufacturing Firms in Sri Lanka.Asian Social Science, 10(18), 50-62.

lxxv. Wijesekara, W. A., Kumara, P. A., and Gunawardana, T. S. (2014). The impact of market orientation and entrepreneurial orientation on performance: A study on small and medium scale garment manufacturers in Sri Lanka. Proceedings of the 3rd International Conference on Management and Economics.Matara, Sri Lanka, 2627 February 2014. Matara, Sri Lanka: Faculty of Management and Finance, University of Ruhuna, Sri Lanka..

lxxvi. Wijethunge, W. A. D. S. (2016). Service Quality, Competitive Advantage and Business Performance in Service Providing SMEs in Sri Lanka. International Journal of Scientific and Research Publications, 6(7), 720 - 729.

lxxvii. Wijetunge, W., and Pushpakumari, M. (2014). Entrepreneurial orientation and business performance of small and medium scale enterprises of Western Province in Sri Lanka.Kelaniya Journal of Management, 2(2), 51-67. http://doi.org/10.4038/kjm.v2i2.6550.

lxxviii. Wirtz J, Heracleous, L, \&Pangarkar N. (2008). 'Managing Human Resources for Service Excellence and Cost Effectiveness at Singapore Airlines'. Managing Service Quality, 18(1), 4-19.

lxxix. Yee, Yeung, and Cheng, (2010), An empirical study of employee loyalty, service quality and firm performance in the service industry Rachel W.Y. Yee a, Andy C.L. Yeung b, T.C. Edwin Cheng by R.W.Y. Yee et al. / Int. J. Production Economics 124 (2010) 109-120

lxxx. Zeithaml, V. A., Berry, L.L. \&Parasuraman, A. (1996). The behavioural consequences of service quality. Journal of Marketing Management, 60(No. April), 31-46. 
lxxxi. Zeithaml, V.A., Parasuraman, A., \& Berry, L.L. (1992). Strategic positioning on the dimensions of service quality. In: Swartz, T.A., Bowen, D.E., Brown, S.W. (eds.) Advances in Services Marketing and Management, vol. 2, pp. 207228, Greenwich: JAI Press.

lxxxii. Zimmerman, M. A., and Chu, H.M. (2013). Motivation, Success and Problems of entrepreneurs in Venezuela. Journal of Management Policy and Practice, 14(2), 76-90.

lxxxiii. Zsido, K. E., and Fenyves, V., (2015). Application of traditional and new approach methods in business performance measurement. Cross-Cultural Management Journal, 17(1), 51-57. 